\title{
Anabases
}

ANABASES Traditions et réceptions de l'Antiquité

$20 \mid 2014$

Varia

\section{Alicia SIMPSON, Niketas Choniates, a historiographical study}

Pablo Cavallero

\section{OpenEdition}

\section{Journals}

Edición electrónica

URL: http://journals.openedition.org/anabases/5175

DOI: 10.4000/anabases.5175

ISSN: 2256-9421

Editor

E.R.A.S.M.E.

\section{Edición impresa}

Fecha de publicación: 1 noviembre 2014

Paginación: 439-441

ISSN: $1774-4296$

\section{Referencia electrónica}

Pablo Cavallero, «Alicia simpson, Niketas Choniates, a historiographical study », Anabases [En línea], 20 |

2014, Puesto en línea el 01 noviembre 2014, consultado el 22 septiembre 2020. URL : http://

journals.openedition.org/anabases/5175; DOI : https://doi.org/10.4000/anabases.5175

Este documento fue generado automáticamente el 22 septiembre 2020.

(c) Anabases 


\title{
Alicia SIMPSON, Niketas Choniates, a historiographical study
}

\author{
Pablo Cavallero
}

\section{REFERENCIA}

Alicia SIMPSON, Niketas Choniates, a historiographical study, Oxford, Oxford University

Press, 2013, $384 \mathrm{p}$.

104,68 euros / ISBN 978-0-19-967071-0

1 Alicia Simpson ( = S. ; Fundación Nacional Helénica), ofrece en estas páginas un estudio de la Historia de Niketas Khoniates ( = N.), fuente insoslayable para conocer el período de la historia bizantina comprendido entre 1118 y 1206, sobre todo de la etapa posterior a 1180. La autora sostiene que el estudio histórico no puede ser escindido del literarioretórico, porque la historiografía era concebida en Bizancio como una obra literaria, hecho que responde a la tradición del género desde la Antigüedad. No pretende ser exhaustiva en el análisis. Emplea la edición de van Dieten (1975). Se ocupa de :

2 I. Autor, vida y obra (p. 11-67) : aquí reseña la carrera pública de N., su huida en ocasión de la caída de la capital y cómo finalmente va a la corte en el exilio, donde cumple diversas tareas, pero nunca recupera el nivel previo, de modo que muere en pobreza y oscuridad.

3 La autora analiza también los vínculos del historiador con sus contemporáneos, a partir de cartas y referencias. Respecto de Mesopotamitis, S. señala que pudo ser el exiliado destinatario de una copia de la Historia y de la Panoplia dogmática, mencionada en el prólogo de esta última obra.

4 Se destina un apartado a dicha obra teológica y otro a los encomios imperiales; S. destaca cómo esas obras complementan los datos de la Historia y la posición que N. tomó en cada caso, señalando las diferencias entre ellas y la Historia : los elogios de los discursos suelen pasar a sarcasmos, a correcciones de lo que no era realista; el autor 
adapta el material al género y a la situación, incluso contradiciéndose. Para S. esto no prueba duplicidad.

5 II. Composición y transmisión de la Historia (p.68-127): S. resume que el editor estableció tres redacciones («breve», "aumentada», ambas inconclusas, y una redacción diversa de la última parte); que hay dos manuscritos « mixtos » (de la breve y de la aumentada) y tres que contienen una metáfrasis. Con numerosos ejemplos, $\mathrm{S}$. demuestra cómo la versión breve elude detalles censurables, por ser el autor un magistrado del régimen, cuya aprobación necesitaba (por ello suprime su propia participación, para dar idea de neutralidad) ; y cómo la versión aumentada, que no debía responder a ningún patrón, es más cínica y sentimental, corrige errores, precisa fechas, añade citas y alusiones literarias, censura y moraliza. Hay un sector final, conocido como De signis, que era independiente y fue añadido a la Historia por la tradición.

6 Señala S. que en esa tradición interfieren manos tardías que sólo afectan lo estilístico. Los cambios importantes respecto de la redacción breve son del autor mismo; en la ampliada, N. ya tenía conciencia del desastre acaecido y lo atribuye a la corrupción y a la incompetencia de los dirigentes.

7 La cantidad de manuscritos probaría la difusión de la obra, mayor que la de otros historiadores. Cree S. que N. habría publicado la versión breve pero, al morir, posiblemente sin haber hecho de la ampliada un ejemplar aparte, se inician las interferencias de esa redacción breve con la ampliada, sin que ésta suplante totalmente a la primera, de modo que surge un texto « intermedio » entre ambas. S. hace reseña del influjo de la obra en textos posteriores, como asimismo de la metáfrasis, siguiendo las opiniones de van Dieten. De esta metáfrasis y de un comentario marginal del ms. $\mathrm{F}$ concluye S. que el texto de N., clasicista, tuvo inicialmente un público selecto que se amplió por el interés que generaba el asunto mismo.

III. Narrativa histórica y biografía imperial (p. 128-213) : reseña los rasgos del género y las opiniones sobre su vínculo con la crónica. $\mathrm{N}$. incluye los grandes hechos de la corte y la milicia, pero también la vida cotidiana; hace selección de hechos vinculados con su entorno y conocimiento ; vinculación de la secuencia de ellos con la historia imperial ; reconstrucción creativa del pasado; emplea técnicas tradicionales y mezcla géneros, rasgo que S. considera innovación en la literatura griega y típico del s. XII (p. 135). La autora estudia la estructura narrativa, detalla el desarrollo de la obra y los libros dedicados a cada emperador. En la presentación de los caracteres se mezcla lo trágico con lo satírico; ellos no son estereotipados, pero tampoco objetivos. Con algunos ejemplos, S. marca la diferencia entre las presentaciones hechas en ambas versiones ; la ampliada acentúa los vicios imperiales y los detalles novelescos y humorís-ticos, usa la animalización ridiculizante, la identificación con personajes míticos y la imaginería bíblica; en algunos casos N. no concuerda con otras fuentes. Asimismo, S. presenta ejemplos del tratamiento, habitualmente en digresiones, de caracteres secundarios.

9 IV. Fuentes, modelos, conceptos. Como fuentes escritas utilizó panegíricos, informes del frente de batalla, pero poca documentación de archivo diplomático. Sigue a Kínnamos, cuya obra complementa con una «adaptación libre» (p. 219) y corrige en algunos detalles a partir de informes orales. También emplea la Captura de Tesalonica de Eustacio, con quien comparte detalles y al que complementa ; sus encomios cortesanos, adaptados libremente, y cartas de corresponsales. Las fuentes orales son testigos de la 
corte y de las batallas, rumores, datos de entrevistas. Pero también incluye su propio testimonio ocular, sobre todo en la toma de la capital.

Destaca la autora los modelos retóricos, señalando que para Bizancio el historiador era un orador, rasgo que creemos propio ya de la historiografía antigua. Destaca S. el influjo de Plutarco, Polibio, Diodoro, Filóstrato. N. comparte con Psellos ideas, detalles y expresiones. S. se detiene en los recursos de narración descriptiva y cuento : N. suele incluir su opinión en conversaciones de los personajes, con lo cual enmascara su intervención, da impresión de libertad de juicio al público y puede incorporar crítica en un género que habitualmente sirve a la propaganda imperial. También se detiene S. en los discursos ficticios, las digresiones y excursus, los proverbios y las generalizaciones, las citas y alusiones, con uso abundante de metáforas, símiles e imágenes.

11 En cuanto a los conceptos históricos, predominan la idea de providencia ; la búsqueda del beneficio común ; la preservación de los hechos contra el olvido ; la justificación del estilo trágico-retórico, sobre todo en ciertos episodios como la caída de Constantinopla.

En la conclusión, S. destaca que la obra es « un espejo de la actitud de N. hacia el tiempo en que vivió» (p.295); que ofrece datos sobre un período menos documentado (1180-1204) y presentado con el prisma de lo ocurrido en 1204. Advierte que faltan muchos estudios sobre N. Los apéndices ofrecen la lista de manuscritos (I) ; un sumario del contenido de la Historia, dividido por reinos pero sin indicar los libros a que corresponden en la secuencia general (II) ; un estudio de la actitud de N. respecto de los latinos, los turcos y los búlgaros, respecto de los cuales es N. la única fuente explicativa de la rebelión Vlach (III). También aporta S. un cuadro de las genealogías de los Komnenoí y los Ángeloi, poco clara en su diagramación y con un error en el reinado de Alejo V; mapas; una bibliografía con sesenta y nueve fuentes primarias y más de quinientos estudios ; $\mathrm{y}$ un útil índice de nombres.

13 Nos parece claro que S. ofrece en este libro una relevante aportación para el conocimiento del autor, del texto, de la historiografía bizantina como género y del momento reflejado. Es muy valioso, tanto para historiadores cuanto para estudiosos de la literatura.

\section{AUTORES}

\section{PABLO CAVALLERO}

Univ. de Buenos Aires-Univ. Católica Argentina-CONICET

pablo.a.cavallero@gmail.com 